\title{
MODEL SPASIAL PERUBAHAN LAHAN SAWAH UNTUK MENDUKUNG KEBIJAKAN LAHAN PERTANIAN PANGAN BERKELANJUTAN (LP2B) DI KABUPATEN SELUMA
}

\author{
Spatial Model Paddy Field To Support Sustainable Food Farming Policy In Seluma \\ District
}

\author{
Mujiono*, Indah Fitria \\ Prodi Agribisnis Universitas Dehasen Bengkulu \\ e-mail:*mujiono@unived.ac.id, ${ }^{2}$ indahfitria@unived.ac.id
}

\begin{abstract}
ABSTRAK
Penelitian dilakukan untuk : (1) membuat model spasial perubahan lahan sawah di kabupaten Seluma antara tahun 2000 - 2010, 2010 - 2019, dan 2000 - 2019, (2) membuat model spasial prediksi perubahan lahan sawah kabupaten Seluma tahun 2032. Metode yang digunakan adalah deskriptif kuantitatif serta analisis menggunakan ArcGIS 10. 2, Envi 5. 1 dan IDRISI Selva 17. Hasil penelitian menunjukkan bahwa sejak tahun $2000-2010$ sawah berkurang seluas 765 ha sedangkan perkebunan dan lahan terbangun justru bertambah, masing-masing menjadi 15.871 ha dan 537 hektar. Kemudian, periode 2010 hingga 2019 perubahan lahan sawah menjadi penggunaan lainnya meningkat 100 persen (1.645 hektar). Sedangkan perkebunan bertambah sekitar 35 persen atau 5.609 hektar. Jadi, dalam kurun waktu 19 tahun kabupaten Seluma telah kehilangan 2.410 ha sawah, sementara di saat yang sama perkebunan mengalami peningkatan luas lahan sebesar 21.479 hektar. Perubahan banyak terjadi di bagian Selatan, sebab wilayah ini memiliki karakteristik fisik lereng $0-2 \%$ atau terkategori datar sehingga mudah dibudidayakan. Hasil model spasial prediksi perubahan lahan sawah antara tahun 2019 hingga 2032 menunjukkan adanya penambahan lahan sawah seluas 557 hektar. Namun lahan perkebunan justru berkurang cukup signifikan yakni seluas 4.156 ha, sedangkan lahan terbuka justru bertambah 3.274 hektar.
\end{abstract}

Kata kunci: model spasial, lahan sawah, LP2B

\begin{abstract}
The purpose of the study is to (1) model spatial change of paddy fields in Seluma district between 2000 -2010, 2010 - 2019, and 2000 - 2019, (2) make a spatial model of the campaign for change in paddy fields in Seluma district in 2032. The method used is quantitative descriptive and analysis using ArcGIS 10. 2,Envi 5. 1 and IDRISI Selva 17. The results of the study show that from 2000 to 2010 the fields werereduced to an area of 765 ha while plantations and land were built up, each becoming 15,881 ha and 537 hectares. Then, in the period 2010 to 2019 the change in land to other uses increased 100 percent (1,645hectares). While the area of land increased by around 35 percent or 5,609 hectares. So, within 19 yearsSeluma district has lost 2,410 hectares, while at the same time an increase of more than 21,479 hectares. Many changes occur in the South, because this region has physical characteristics of slopes $0-2 \%$ or flat categorized so that it is easily cultivated. The results of the spatial model predictions of changes in paddy fields between 2019 and 2032 show the number of paddy fields covering 557 hectares. However, the
\end{abstract}


decreasing land area is quite significant, covering an area of 4.156 ha, while the area of open land has increased by 3.274 hectares.

Keywords: spatial model, paddy field, LP2

\section{PENDAHULUAN}

Kabupaten Seluma merupakan salah satu penyuplai beras terbesar di provinsi Bengkulu. Jaraknya yang relatif dekat dengan ibukota provinsi menjadikannya referensi stabilitas pangan bagi kabupaten sekitarnya. Dari 40 komoditas pertanian yang ada, padi sawah merupakan subsektor tanaman pangan yang menjadi unggulan (leading sector), disusul dengan subsektor perkebunan seperti karet, kayu manis dan pinang, (anto, 2013). Data terakhir produksi beras di daerah ini mencapai 82,727 ton dengan luas panen 21,114 ha (BPS Prov. Bengkulu, 2015). Pemerintah setempat terus mendorong ketahanan pangan dengan dikeluarkannya sejumlah kebijakan atau peraturan daerah serta penyuluhan kepada petani.

Saat ini, upaya pemerintah daerah dalam mewujudkan ketahanan pangan sedang dihadapkan pada praktik perubahan lahan sawah yang semakin memprihatinkan dan perlu ditertibkan. Sementara lahan sawah bersifat rigid artinya tidak semua lahan pertanian bisa dijadikan sawah sebab memiliki karakter khusus yaitu tersedianya air yang cukup dengan tingkat kesuburan yang tinggi, (Widayati, 2015).

Pada tahun 2009 pemerintah bersama-sama dengan DPR mengesahkan Undang-Undang No. 41Tahun 2009 tentang Lahan Pertanian Pangan Berkelanjutan (LP2B). Undang-undang ini diharapkan dapat menahan laju perubahan lahan sawah khususnya sawah dengan irigasi teknis sehingga dapat menopang ketahanan pangan, (Direktorat Pangan dan Pertanian, 2015).

Model perubahan penggunaan lahan bisa menjadi instrumen untuk memahami dinamika perubahan lahan sawah dan dampaknya terhadap ketersediaan beras sekaligus sebagai sistem peringatan dini dampak perubahan penggunaan lahan di masa depan, (Latuamury \& Bokiraiya, 2013). Bila pola perubahan yang berlangsung dalam suatu rentang waktu dimodelkan secara dinamik dan berbasis spasial maka akan diperoleh informasi tentang lokasi (where) dan luas (how much) yang dimungkinkan terjadi di masa depan.

Model spasial perubahan penggunaan lahan yang di dalamnya memuat prediksi perubahan lahan sawah diperlukan sebagai bahan antisipasi terhadap perubahan fungsi pemanfaatan ruang (Dwinanto, dk,016). Upaya pembangunan basis data spasial harus 
dilakukan oleh pemerintah daerah seperti dukungan teknologi penginderaan jauh dan sistem informasi geografis akan mempermudah proses pemantauan dinamik penggunaan lahan, proses pembaruan dan analisis spasial yang dibutuhkan secara lebih cepat dan lebih akurat, (Direktorat Pangan dan Pertanian, 2015).

Berdasarkan uraian di atas, penelitian ini bertujuan untuk; (1) mengetahui model spasial perubahan lahan sawah di kabupaten Seluma antara tahun 2000 sampai 2010, 2010 sampai 2019, dan 2000 sampai 2019, (2) membuat model spasial prediksi perubahan lahan sawah kabupaten Seluma tahun 2032 (sesuai Perda No. 2 Tahun 2013: RTRW Kab. Seluma).

\section{METODE PENELITIAN}

Penelitian dilaksanakan di kabupaten Seluma (non kawasan hutan) dengan luas 150.678 hektar. Kabupaten Seluma adalah salah satu kabupaten di provinsi Bengkulu dengan ibu kotanya Tais. Terbentuk berdasarkan Undang-undang Nomor 3 Tahun 2003 dan memiliki jumlah penduduk 181.242 Jiwa yang terdiri dari; perempuan 93.134 jiwa dan lakilaki 88.108 jiwa, (BPS Prov. Bengkulu, 2015). Secara administrasi batas wilayah kabupaten Bengkulu Utara adalah :

- Sebelah Utara : kota Bengkulu

- Sebelah Selatan : kabupaten Bengkulu Selatan

- Sebelah Timur : kabupaten Empat Lawang

- Sebelah Barat : samudera Hindia

\section{Diagram Alir Penelitian}

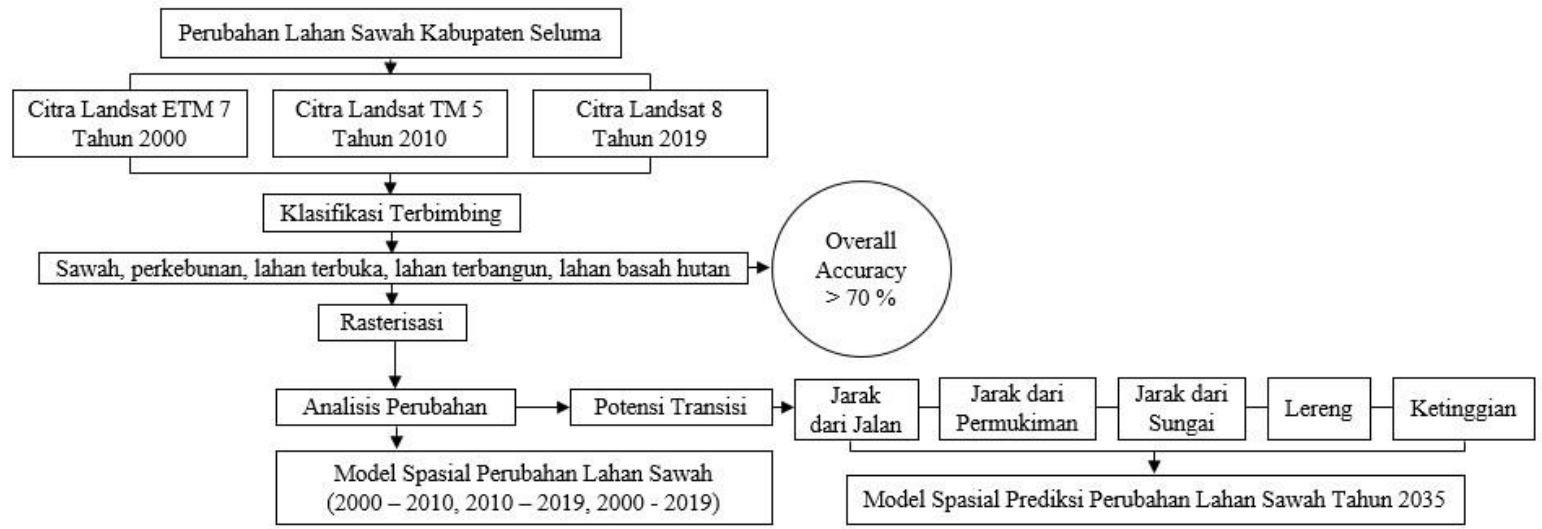

Gambar 1. Diagram Alir Penelitian 


\section{Populasi dan Sampel Penelitian}

Populasi dalam penelitian ini adalah lahan sawah (sawah irigasi dan non irigasi) di kabupaten

Seluma. Sedangkan untuk pengambilan sampelnya terdiri dari dua tahapan, yaitu:

1) Klasifikasi tutupan lahan, pada tahap ini pengambilan sampel digunakan untuk membuat Region of Interest (ROI) masing-masing kelas penggunaan lahan melalui metode klasifikasi terbimbing (supervised). Jumlah sampel diambil ada 60 ROI yang mewakili enam kelas penggunaan lahan. Pada tahapan ini uji akurasi dilakukan menggunakan software pengolahan data indraja; ENVI 5. 1.

2) Menguji akurasi, pada tahapan ini pengambilan sampel dilakukan untuk membuat poligon atau titik yang mewakili masing-masing penggunaan lahan baik pada hasil klasifikasi 2019 maupun hasil prediksi 2019. Data poligon (ROI) digunakan untuk uji akurasi hasil klasifikasi penggunaan lahan tahun 2019 menggunakan ENVI 5. 1. Sementara data titik digunakan untuk uji akurasi prediksi penggunaan lahan 2019 menggunakan software Sistem Informasi Geografis; ArcMap 10. 2. Kedua sampel tersebut menggunakan citra tahun 2019 resolusi tinggi, yakni Google Earth.

\section{Teknik Pengolahan dan Analisis Data}

1) Klasifikasi penggunaan lahan

Tahap awal pengolahan data dilakukan dengan mengklasifikasi penggunaan lahan pada citra Landsat TM 5 (tahun 2000 dan 2010) dan Landsat 8 OLI TIRS (tahun 2019). Klasifikasi lahan merujuk pada Standar Nasional Indonesia (SNI) 7645:2010, diantaranya; sawah, perkebunan, lahan terbuka, lahan terbangun, lahan basah dan hutan.

2) Geoprocessing

Dilakukan untuk menjembatani pemodelan spasial berikutnya. Kegiatan meliputi; reklasifikasi, rasterisasi (.rst), termasuk konversi ke imagine (.img) dan beberapa tahapan lainnya jika dibutuhkan.

3) Analisis dan prediksi perubahan lahan sawah

Overlay merupakan teknik yang digunakan dalam analisis perubahan. Sedangkan tahap prediksi perubahan dilakukan dengan mempersiapkan data penggunaan lahan dan faktor pendorong menggunakan software ArcMap 10. 2. berupa data imagine (.img) 
selanjutnya menyamakan sistem proyeksi (plane), ukuran sel (cell size), jumlah baris dan kolom (column and row), serta nama dan jumlah tutupan lahan. Setelah data disiapkan, kemudian buat project dan masukkan data di Land Change Modeller (LCM). Secara umum proses analisis dilakukan melalui sub menu berikut; (1) Change Analysis yang meliputi; LCM Project Parameter, Change Analysis, Change Maps, Spatial of Trend. (2) Transition Potential yang meliputi; Transition Sub-Model, Transition Submodel Stucture, Run Transition Sub-Model. (3) Change Prediction yang meliputi; Change Demand Modelling, Change Allocation, dan Validation.

4) Validasi hasil klasifikasi dan prediksi

Uji akurasi pada hasil klasifikasi penggunaan lahan dilakukan menggunakan ENVI 5. 1. pada tool Confusion Ground Truth ROIs (Region of Interest). Sementara itu, uji akurasi pada hasil prediksi dilakukan menggunakan ArcMap 10. 2. Akurasi pemetaan dapat diterima apabila akurasi keseluruhan atau overall acurracy $\geq 70 \%$ (Purwadhi, 2001). Sedangkan akurasi Kappa atau Kappa Coefficient memiliki rentang kategori yaitu; $0-0,4$ (rendah), 0,4 - 0,8 (sedang), 0,8 - 1 (tinggi). Menurut Lillesand, dkk (2007), secara matematis, Overall Accuracy dan Kappa Accuracy dapat dihitung dengan rumus berikut.

$$
O A(\text { Overall Accuracy })=\frac{\sum_{i=1}^{r} x_{i i}}{N_{\mathrm{N}}} \times 100 \%
$$

Keterangan:

Xii = nilai diagonal dari matrik kontingensi baris ke-i dan kolom ke-i

$\mathrm{N}=$ banyaknya piksel dalam contoh

$O A($ Overall Accuracy $)=\frac{N \sum_{i=1}^{r} x_{i i}-\sum_{i=1}^{r}\left(x i^{+} . x i^{+1}\right)}{N^{2}-\sum_{i=1}^{r}\left(x i^{+} . x i^{+1}\right)} \times 100 \%$

\section{Keterangan:}

$\mathrm{R}=$ jumlah baris dalam matrik kesalahan

$\mathrm{Xii}=$ jumlah observasi pada baris 1 dan lapa 1

$\mathrm{xi}+=$ jumlah observasi pada baris 1

$\mathrm{x}+\mathrm{i}=$ jumlah observasi pada lajur 1

$\mathrm{N}=$ jumlah total piksel pada matrik 


\section{HASIL DAN PEMBAHASAN}

Berdasarkan uji validasi klasifikasi penggunaan lahan dengan metode terbimbing (supervised) menggunakan software ENVI 5.1 pada citra tahun 2019 menghasilkan nilai akurasi keseluruhan sebesar 83,1 persen (Gambar 2), itu artinya klasifikasi dapat diterima sekaligus referensi bagi citra lainnya baik citra Landsat ETM 7 Tahun 2000 maupun Landsat TM 7 Tahun 2010.

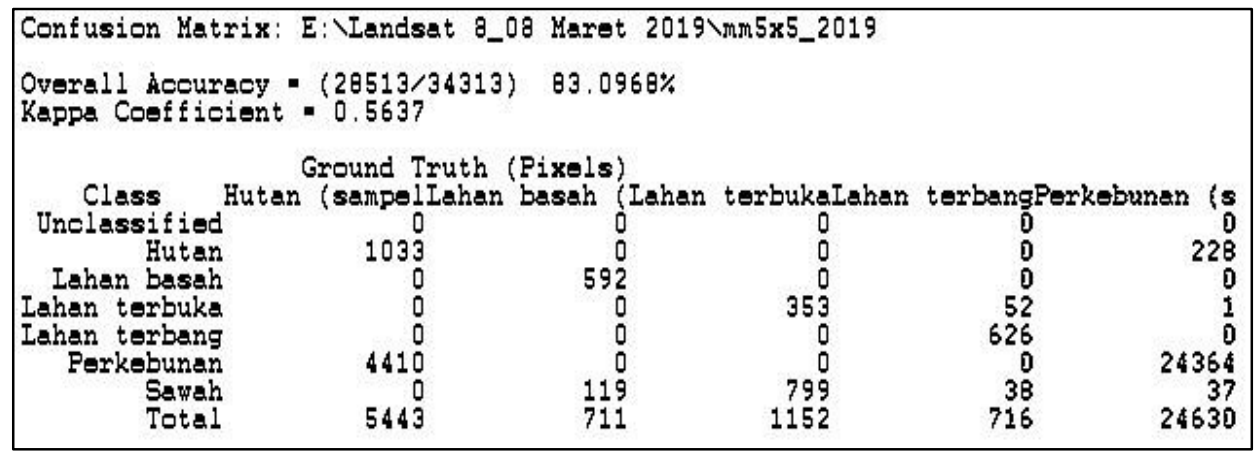

Gambar 3.1. Nilai Akurasi (Overall Accuracy) Hasil Klasifikasi Penggunaan Lahan Tahun 2019

Oleh karena validasi sudah memenuhi standar, maka model spasial layak untuk dilanjutkan dan akan dideskripsikan pada masing-masing sub bab berikut ini.

\section{Perubahan Lahan Sawah di Kabupaten Seluma}

Periode Tahun 2000 - 2010

Perubahan lahan pada rentang tahun 2000 - 2010 menyebabkan kabupaten Seluma kehilangan 765 ha sawah. Fenomena ini disebabkan oleh meningkatnya luas perkebunan baik sawit maupun karet seluas 15.871 hektar. Konversi lahan sawah menjadi perkebunan terjadi di semua wilayah dengan ketinggian bervariasi antara $0-716 \mathrm{~m}$ dpl dan tingkat kemiringan lereng $0-2 \%$. Jika dilihat dari persentase lerengnya, wilayah yang berubah terkategori datar, maka wajar apabila konversi lahan sawah menjadi lahan terbangun juga cukup signifikan, yakni seluas 537 hektar.

Periode Tahun 2010 - 2019

Pada periode ini, tren perubahan lahan sawah meningkat 100 persen dibandingkan periode sebelumnya, yakni 1.645 hektar. Namun, perkebunan hanya meningkat 35 persen, yakni 5.609 hektar. Sedangkan lahan terbangun bertambah 91 ha atau 
hanya 17 persen saja. Perubahan lahan sawah banyak terjadi di bagian Selatan, oleh karena keadaan fisik wilayah yang cenderung datar sehingga mudah untuk diusahakan.

Periode Tahun 2000 - 2019

Dalam kurun waktu 19 tahun, kabupaten Seluma telah kehilangan 2.410 ha sawah. Perkebunan berkontribusi besar dalam perubahan tersebut dengan luas 21.479 hektar. Kemudian kontributor lainnya yang juga turut berperan adalah lahan terbangun seluas 628 hektar. Grafik perubahan lahan dapat dilihat pada Gambar 3 berikut ini.

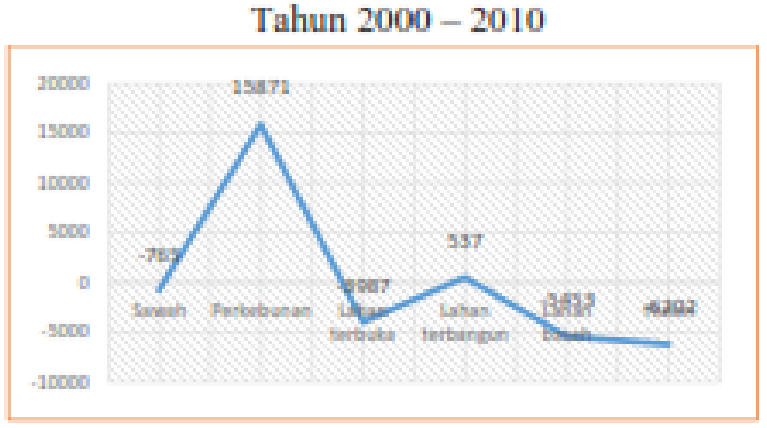

Tahun $2000-2019$

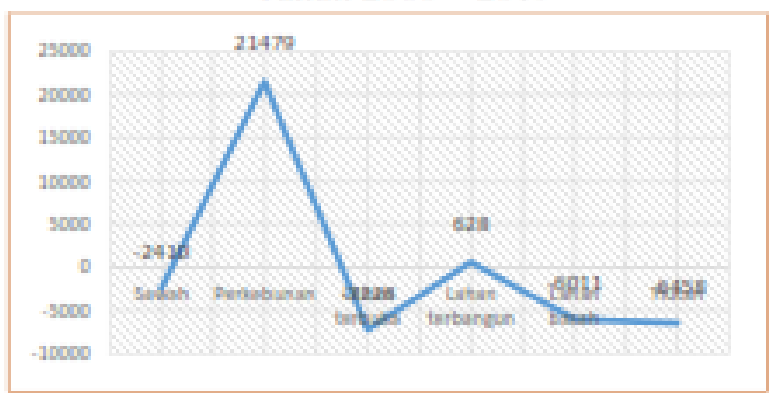

Tahun $2010-2019$

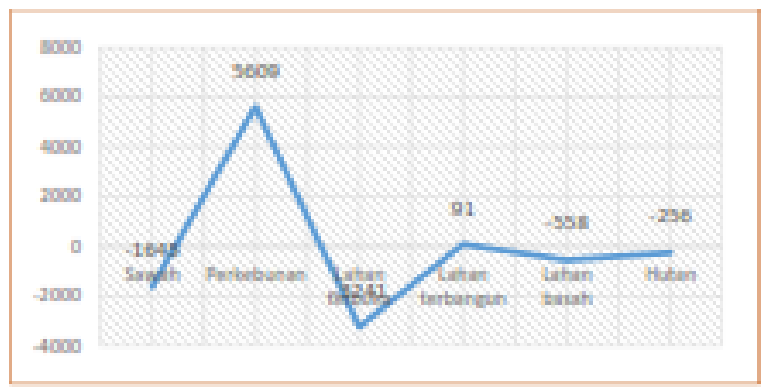

Tahun $2019-2032$

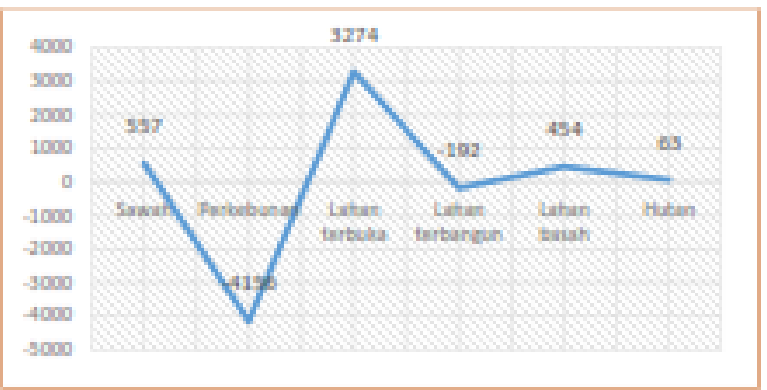

Gambar 3.. Luas Perubahan Lahan Sawah di Kabupaten Seluma

\section{Model Spasial Prediksi Perubahan Lahan Sawah Tahun 2032}

\section{Faktor Pendorong Lahan Sawah}

Pada dasarnya hampir tidak ada perencanaan yang tidak dilakukan di atas lahan. Oleh karena itu, informasi penggunaan lahan secara spasial (lokasi) dan temporal (waktu) sangat diperlukan dalam proses perencanaan dan pengambilan keputusan jangka panjang. Simulasi penggunaan lahan pada tahun 2032 dimaksudkan dapat memberikan pertimbangan penataan ruang di masa yang akan datang.

Lahan sawah tidak mungkin berubah jika tidak dipengaruhi oleh faktor-faktor yang ada disekitarnya, baik fisik maupun sosial. Secara fisik perubahan lahan sawah 
dipengaruhi oleh setidaknya; jarak dari jalan, dari permukiman, dari sungai, ketinggian dan lereng. Faktor - faktor tersebut selanjutnya akan diuji menggunakan korelasi Cramer's V. Jika nilai dari salah satu variabel pendorong memiliki nilai $\geq 0,15$ maka variabel tersebut berpengaruh. Namun jika nilai $\leq 0,15$ maka variabel tersebut kurang atau bahkan tidak berpengaruh terhadap perubahan lahan sawah.

Berdasarkan nilai rata-rata uji korelasi Cramer's V, permukiman lebih berpengaruh terhadap perubahan lahan sawah dengan nilai 0,16 dibandingkan dengan faktor jarak dari jalan, yakni dengan nilai 0,12. Hasil tersebut memiliki makna bahwa pertambahan penduduk berpengaruh pada meningkatnya kebutuhan dan perubahan lahan sawah. Sementara jalan berperan sebagai akses ke lahan pertanian.

Setelah melakukan uji korelasi Cramer's V di atas, langkah selanjutnya yaitu melakukan uji transisi potensial. Sesuai dengan tema yang dipilih, maka sub model yang di uji hanya lahan "Sawah". Pengujian dilakukan dengan pengulangan (iterasi) sebanyak 100.000 kali (maksimum) dengan harapan dapat mencapai akurasi > 50 persen. Adapun model statistik yang digunakan yaitu jaringan syaraf tiruan (MLP Neural Network). Hasil iterasi yang dilakukan pada sub model lahan "sawah" memiliki nilai akurasi sebesar 60,17 persen atau dengan kata lain potensi transisi dapat diterima sehingga memiliki tingkat pengaruh dan kepercayaan yang baik seperti yang terlihat pada gambar 4 berikut ini.

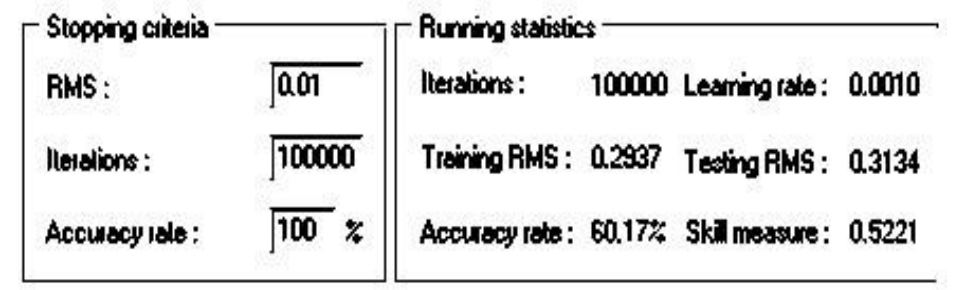

Gambar 4 Iterasi Transisi Potensial pada Sub Model Lahan "Sawah"

\section{Prediksi Perubahan Lahan Sawah Tahun 2019 - 2032}

Tingginya pengaruh faktor pendorong pada uji Cramer's V khususnya permukiman dan terpenuhinya nilai akurasi transisi potensial, maka modal untuk membuat model spasial perubahan lahan sawah semakin memungkinkan untuk dilakukan. Merujuk pada RTRW Kabupaten Seluma, maka pembuatan model spasial dilakukan hingga tahun 2032.

Jika pada periode sebelumnya, lahan sawah cenderung mengalami penurunan, maka berbeda dengan periode tahun 2019 - 2032 yang mengalami penambahan seluas 557 ha. Pada model ini, perubahan lahan sawah banyak terjadi di sisi Selatan dengan karakteristik 
fisik wilayah yang cenderung datar dan mudah untuk diintervensi/ dibudidayakan. Selain itu, lahan basah dan hutan juga mengalami perubahan, yakni masing - masing bertambah 454 ha dan 63 ha. Perubahan lahan perkebunan, jika pada periode sebelumnya semakin bertambah, pada model kali ini justru berkurang seluas 4.156 ha sedangkan lahan terbuka bertambah menjadi 3.274 ha. Fenomena tersebut sangat dimungkinkan dipengaruhi oleh kegiatan peremajaan (replanting) perkebunan terutama sawit. Menurut Mardhika \& Sudrajat (2015), kelapa sawit merupakan tanaman tahunan yang dapat berproduksi secara ekonomis sampai umur 25-30 tahun. Jadi jika dihitung sejak tahun 2000 sampai dengan 2032, maka umur sawit tersebut sudah 32 tahun. Pada Gambar 5. di bawah ini disajikan peta perubahan lahan dalam empat periode sekaligus.
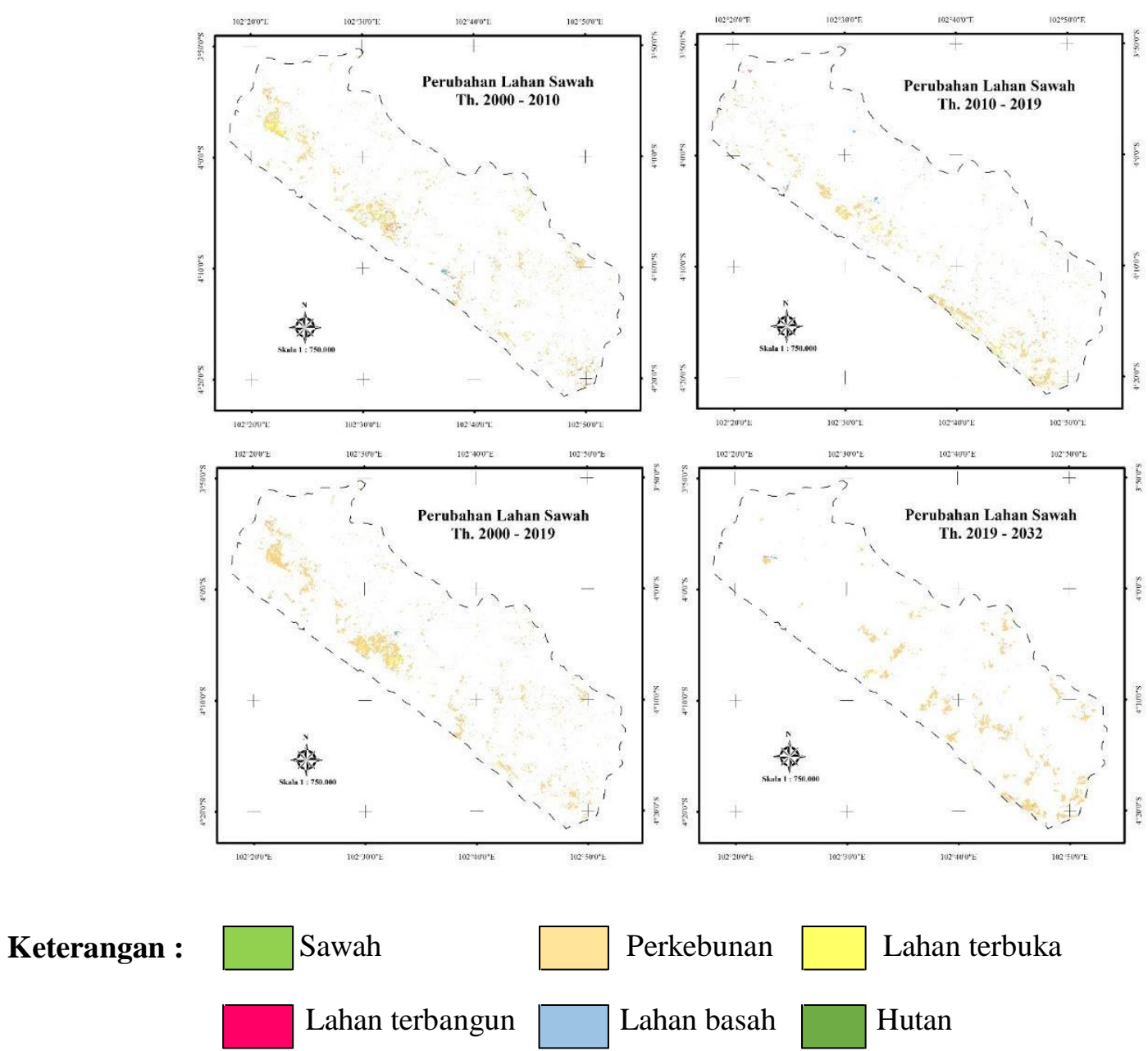

Gambar 5. Perubahan Lahan Sawah di Kabupaten Seluma 


\section{KESIMPULAN}

1. Tahun 2000 hingga 2010, lahan sawah di kabupaten Seluma berkurang seluas 765 ha, sedangkan perkebunan bertambah menjadi 15.871 ha. Persawahan juga telah dimanfaatkan untuk permukiman, terbukti dengan bertambahnya lahan terbangun seluas 537 ha.

2. Tahun 2010 hingga 2019 perubahan lahan sawah menjadi penggunaan lainnya meningkat menjadi $100 \%$ dari periode sebelumnya, yakni seluas 1.645 ha. Sedangkan lahan perkebunan bertambah sekitar 35 persen atau 5.609 ha

3. Kurun waktu 19 tahun, kabupaten Seluma telah kehilangan 2.410 ha sawah, sementara di saat yang sama perkebunan mengalami peningkatan luas lahan sebesar 21.479 ha. Jika dilihat dari aspek spasial, perubahan lahan sawah banyak terjadi di bagian Selatan, sebab wilayah ini memiliki karakteristik fisik lereng $0-2 \%$ atau terkategori datar terutama perubahan ke lahan terbangun, misal; permukiman.

4. Hsil model spasial prediksi perubahan lahan sawah antara tahun 2019 hingga 2032 menunjukkan adanya penambahan lahan sawah seluas 557 ha. Namun pada prediksi kali ini, lahan perkebunan justru berkurang cukup signifikan yakni seluas 4.156 ha, sedangkan lahan terbuka justru bertambah 3.274 ha. Fenomena ini disebabkan oleh adanya kegiatan peremajaan (replanting) di areal perkebunan terutama sawit. Jika dihitung sejak tahun $2000\left(\mathrm{~T}^{0}\right)$ maka sampai dengan tahun 2032, umur sawit di wilayah ini sudah mencapai 32 tahun.

5. Perubahan lahan sawah akan mengakibatkan terganggunya ketersediaan dan stabilitas pangan bagi kabupaten Seluma dan sekitarnya. Sebab sampai dengan saat ini, beras sebagai kebutuhan pokok tidak tergantikan oleh adanya sawit maupun karet. Implementasi kebijakan dan penentuan lokasi Lahan Pertanian Pangan Berkelanjutan (LP2B) layak untuk segera dilakukan sebagai upaya pengawasan terhadap ketersediaan lahan sawah.

\section{UCAPAN TERIMA KASIH}

Ucapan terima kasih disampaikan kepada Direktorat Jenderal Penguatan Riset dan Pengembangan (c.q Direktorat Riset dan Pengabdian Masyarakat - DRPM Ristekdikti), Lembaga Layanan Pendidikan Tinggi Wilayah II (L2DIKTI - II), serta Lembaga Penelitian dan Pengabdian kepada Masyarakat (LPPM) Universitas Dehasen Bengkulu. 


\section{DAFTAR PUSTAKA}

BPS Provinsi Bengkulu, 2015, Luas Panen, Produktivitas dan Produksi Padi Sawah Menurut Kabupaten/Kota di Provinsi Bengkulu Tahun 2013.

Direktorat Pangan dan Pertanian (Indonesia), 2015, Evaluasi Implementasi Kebijakan Lahan Pertanian Pangan Berkelanjutan, Bappenas, Jakarta.

Dwinanto AAD, Munibah K, Untung S., 2016, Model Perubahan dan Arahan Penggunaan Lahan untuk Mendukung Ketersediaan Beras di Kabupaten Brebes dan Kabupaten Cilacap. Tata Loka. No.1, Vol.18, 157 - 71,: https://ejournal2.undip.ac.id/ index.php/tataloka/article/view/688/pdf

Hardyanto., 2013, Analisis Komoditas Unggulan Sektor Pertanian Di Kabupaten Seluma Provinsi Bengkulu, Skripsi,Univ. Bengkulu, Bengkulu

Latuamury, Bokiraiya, 2013, Kajian konseptual pemodelan perubahan penggunaan lahan untuk studi ilmu lingkungan, J. Teknosains. No.1, Vol.3, 8-24,; https://jurnal.ugm.ac.id/teknosains/article/view/6124/4831

Lillesand, T.M., Kiefer, R.W. and Chipman, J.W., 2007, Remote Sensing and Image Interpretation. Ed.6, John Wiley \& Sons, New York.

Mardhika L. D., Sudradjat, 2015, Respons Pertumbuhan Tanaman Kelapa Sawit (Elaeis guineensis) Belum Menghasilkan Umur DuaTahun terhadap Pemupukan Kalsium, Bul. Agrohorti, No.1, Vol.3, 110 - 118,: https://journal.ipb.ac.id/ index.php/bulagron/article/viewFile/14834/10945

Purwadhi, S. Hardiyanti, 2001, Interpretasi Citra Digital, Grasindo, Jakarta.

Widayati, W., 2015, Kebijakan Perlindungan Lahan Pertanian Pangan Berkelanjutan Di Kabupaten Demak, J. Ilmiah Ilmu Pemerintahan, No.1, Vol.1, 5 - 11,; https://ejournal2.undip.ac.id/index.php/jiip/article/view/787/568 